\title{
KELIMPAHAN LARVA UDANG PENAEID PADA EKOSISTEM MANGROVE DI DESA PASAR BANGGI, KABUPATEN REMBANG
}

\author{
Abundance of Penaeid Shrimp Larvae on Mangrove Ecosystem in Pasar Banggi Village, Rembang \\ Pratiwi Genesi Siagian, Djuwito*), Suradi Wijaya Saputra \\ Program Studi Manajemen Sumberdaya Perairan \\ Fakultas Perikanan dan Ilmu Kelautan, Universitas Diponegoro \\ J1. Prof. Soedarto, SH, Tembalang, Semarang, Jawa Tengah - 50275, Telp/Fax. +6224 7474698 \\ Email : pratiwisiagian@gmail.com
}

\begin{abstract}
ABSTRAK
Peran ekosistem mangrove sebagai daerah asuhan dan daerah mencari makan bagi larva udang, dimana sumber benih udang secara alami dapat dimanfaatkan oleh petambak. Oleh karena itu, keberadaan larva udang penaeid dapat memberikan informasi tentang data sebaran larva. Tujuan penelitian ini untuk mengetahui jenis larva udang penaeid di ekosistem mangrove, mengetahui kelimpahan dan dominansi larva udang penaeid dan mengetahui hubungan dan pengaruh variabel kualitas air terhadap kelimpahan larva udang penaeid pada ekosistem mangrove di Desa Pasar Banggi, Kabupaten Rembang. Penelitian dilakukan pada bulan April-Mei 2016. Lokasi penelitian terdiri dari mangrove umur 50 tahun, 7 tahun dan 3 tahun. Teknik pengambilan sampel larva udang dalam penelitian menggunakan metode stratified sampling. Pengambilan sampel larva udang penaeiddengan mendorong scoop netsejauh 50 meter, mesh size 0,5 mm. Jenis larva udang penaeid yang ditemukan selama penelitianyaitu Sicyonia, Trachypenaeus, Xyphopenaeus, Penaeus dan larva tidak teridentifikasi.Larva genus Trachypenaeus dan Penaeus selalu muncul pada ketiga wilayah, sedangkan genus Sicyonia dan Xyphopenaeus tidak muncul satu kali pada mangrove umur 7 tahun dan 3 tahun.Kelimpahan larva udang penaeid tertinggi diperolehselama penelitian pada mangrove umur 3 tahun diikuti mangrove umur 7 tahun dan kelimpahan terendah mangrove umur 50 tahun. Jenis larva udang penaeid yang paling banyak ditemukan adalah Penaeus $76,559 \%$, sedangkan yang paling sedikit adalah Sicyonia 0,215\%. Nilai indeks dominansi berkisar 0,371-0,523. Berdasarkan hasil uji multikolinieritas menunjukkan antara suhu, kecepatan arus, kecerahan dan salinitas memiliki hubungan korelasi kuat. Uji analisis regresi berganda menunjukkan antara suhu, kecepatan arus, kecerahan dengan kelimpahan larva udang penaeid berpengaruh positif, sedangkan salinitas dengan kelimpahan larva udang penaeid berpengaruh negatif.
\end{abstract}

Kata Kunci : Ekosistem mangrove; Larva udang penaeid; Kelimpahan; Desa Pasar Banggi, Kabupaten Rembang

\begin{abstract}
The role of mangrove ecosystems as the breeding and feeding area for shrimp larvae can be used by farmers naturally. Therefore, the existence of penaeid shrimp larvae can provide information about the distribution of the larvae. The purpose of this study is to determine the type of penaeid shrimp larvae in the mangrove ecosystem, to determine the abundance and dominance of penaeid shrimp larvae and to determine the results of multicoliniearity test and multiple regression analysisof penaeid shrimp larvae in the mangrove ecosystem in Pasar Banggi Village, Rembang. The study was conducted on April-Mei 2016. The location of research consists of mangrove age of 50 years, mangrove age of 7 years and mangrove age of 3 years. The sampling technique for collecting the shrimp larvae is stratified sampling method. Penaeid shrimp larvae sampling was done by pushing scoop net as far as 50 meters, mesh size of $0.5 \mathrm{~mm}$. Penaeid shrimp larvae type that were found during the researchare Sicyonia, Trachypenaeus, Xyphopenaeus, Penaeus and unidentified larvae. Larvae genus Trachypenaeus and Penaeus always appear in the all three areas, while the genus Sicyonia and Xyphopenaeus do not appear once in mangrove age of 7 years and mangrove age of 3 years. The highest abundance of penaeid shrimp larvae obtained during the study in mangrove age of 3 years followed mangrove age of 7 years and the lowest abundance in mangrove age of 50 years. Penaeid shrimp larvae type most commonly found are Penaeus $76.559 \%$, while the least is Sicyonia $0.215 \%$. Dominance index values ranged from 0.371 to 0.523 . Based on the results of multi-coliniearity test, temperature, current speed, brightness and salinity have strong correlation. Multiple regression analysis showed that the relation between temperature, current speed, brightness with the abundance of penaeid shrimp larvae are positive, while the relation between salinity with the abundance of penaeid shrimp larvae is negative.
\end{abstract}

Keywords :Mangrove ecosystem; Penaeid shrimp larvae; Abundance; Pasar Banggi Village, Rembang

*) penulis penanggungjawab

${ }^{\text {C }}$ Copyright by Management of Aquatic Resources (MAQUARES)

412 


\section{PENDAHULUAN}

Desa Pasar Banggi, Kabupaten Rembang, memiliki kawasan hutan mangrove yang sangat luas. Hutan mangrove penting bagi larva udang penaeid sebagai daerah asuhan (nursery ground), daerah mencari makan (feeding ground) dan daerah pemijahan (spawning ground).

Larva udang penaeid merupakan fase awal dari pertumbuhan udang.Siklus hidup udang penaeid yang terkait dengan mangrove adalah telur-telur larva udang masuk ke estuarin sampai stadia juvenildansaat memasuki stadia udang dewasa bermigrasi ke laut untuk memijah.Menurut Dall et al. (1990), telur udang menetas menjadi larva yang bersifat planktonik terbawa oleh arus menuju daerah estuarin sampai stadia juvenil untuk tumbuh menjadi udang dewasa. Udang dewasa akan kembali ke laut lepas untuk memijah. Ekosistem mangrove dijadikan sebagai sumber benih udang penaeid secara alami, sehingga dapat dimanfaatkan oleh petambak. Kondisi lingkungan yang sesuai dan tidak adanya tekanan penangkapan pada daerah asuhan akan mendukung ketersediaan sumberdaya udang secara berkelanjutan.

Tujuan penelitian adalah (1)mengetahui jenis larva udang penaeid pada ekosistem mangrove di Desa Pasar Banggi, Kabupaten Rembang; (2) mengetahui kelimpahan dan dominansi larva udang penaeid di ekosistem mangrove; dan (3) mengetahui pengaruh dan hubungan variabel kualitas air terhadap kelimpahan larva udang penaeid pada ekosistem mangrove.

\section{MATERI DAN METODE PENELITIAN}

Penelitian dilakukan pada ekosistem mangrove di Desa Pasar Banggi, Kabupaten Rembang.Pengambilan sampel dilakukan di 3 lokasi yaitu wilayah A, B dan C (Gambar 1) dengan mempertimbangkan umur mangrove.Pengambilan sampel dilakukan 3 kali ulangan, setiap minggu dilakukan sampling 1 kali pada setiap wilayah. Sampling larva udang penaeid menggunakan scoop net dengan mesh size 0,5 mm dan panjang dorongan sejauh 50 meter pada masing-masing wilayah. Sampel larva dimasukkan ke dalam botol sampel volume $250 \mathrm{ml}$ yang sudah disediakan sebelumnya, kemudian diberi alkohol $70 \%$ yang berfungsi sebagai pengawet.

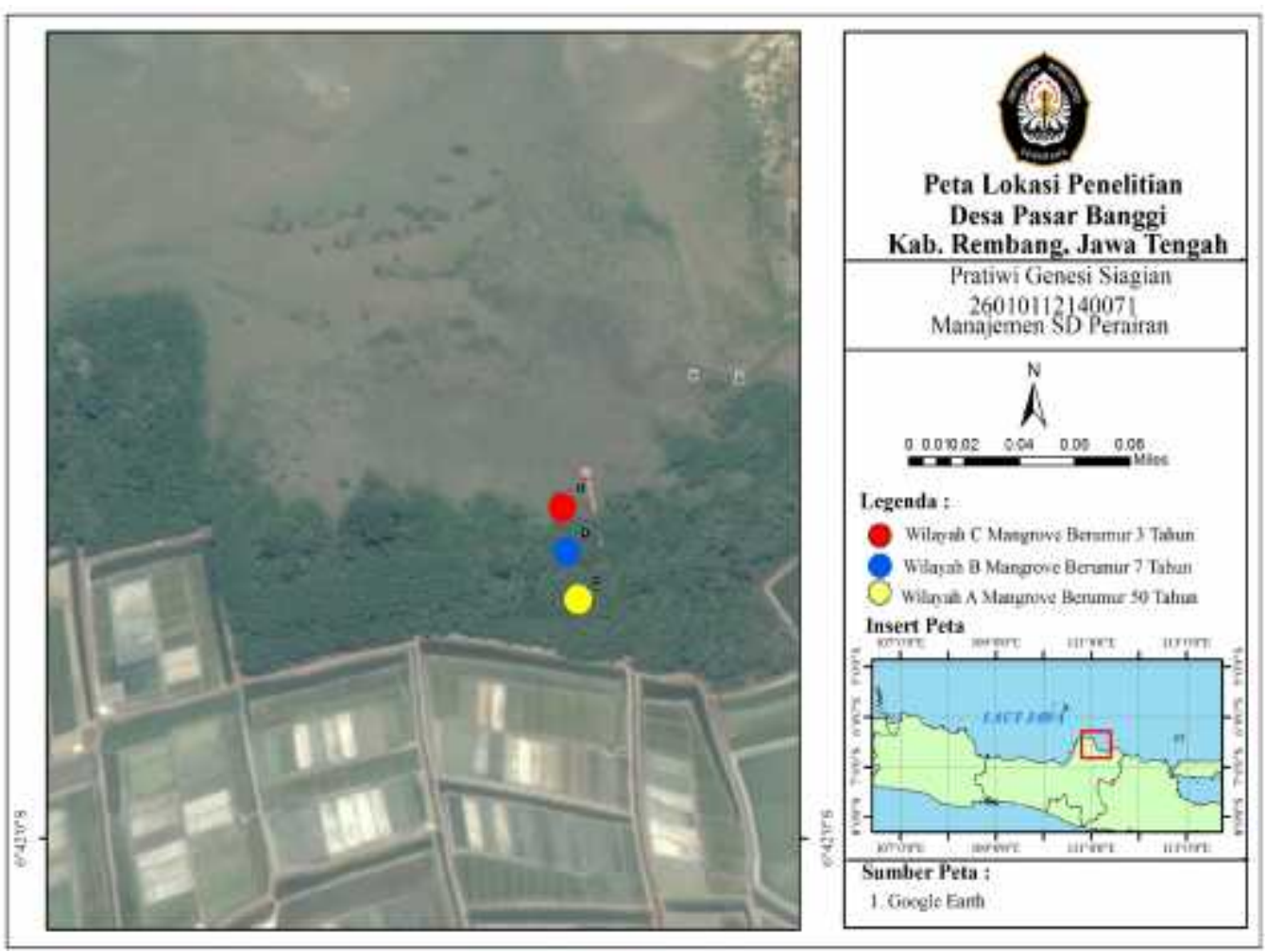

Gambar 1. Peta Lokasi Penelitian

\section{Identifikasi larva udang penaeid}

Identifikasi larva udang penaeid menggunakan buku identifikasi Naamin, 1975.

\section{Pengukuran kondisi perairan}

Pengukuran kualitas perairan dilakukan bersamaan dengan sampling larva pada setiap wilayah penelitian, meliputi suhu menggunakan termometer air raksa, kecerahan dan kedalaman menggunakan secchi disk, kecepatan arus menggunakan bola arus (jeruk) dan stopwatch, salinitas menggunakan hand refraktometer dan $\mathrm{pH}$ menggunakan $\mathrm{pH}$ universal.

Data larva udang penaeid yang tertangkap dianalisis secara deskriptif dengan menghitung kelimpahandan indeks dominansi (C) (Odum, 1993). Untuk melihat hubungan antar variabel dilakukan uji multikolinieritas dan

\footnotetext{
${ }^{\complement}$ Copyright by Management of Aquatic Resources (MAQUARES)
} 
melihat pengaruh antara parameter kualitas air dengan kelimpahan larva udang penaeid digunakan analisis regresi berganda (Kadir, 2015).

\section{HASIL DAN PEMBAHASAN}

Hasil

a. Parameter Kualitas Perairan di Lokasi Penelitian

Pengukuran parameter kualitas air meliputi suhu, kecepatan arus, kecerahan, kedalaman, pH dan salinitas. Adapun hasil pengukuran parameter kualitas air tersaji pada Tabel 1.

Tabel 1. Kualitas Perairan Selama Penelitian

\begin{tabular}{clclll}
\hline \multirow{2}{*}{ No. } & \multirow{2}{*}{ Parameter } & \multirow{2}{*}{ Satuan } & \multicolumn{3}{c}{ Kisaran Nilai } \\
\cline { 4 - 6 } & & & \multicolumn{1}{c}{ Wilayah A } & \multicolumn{1}{c}{ Wilayah B } & \multicolumn{1}{c}{ Wilayah C } \\
\hline 1 & Suhu & ${ }^{\circ} \mathrm{C}$ & $28-33$ & $28-33$ & $27-33$ \\
2 & Kecerahan & $\mathrm{cm}$ & $13,5-35,5$ & $26,5-31,5$ & $20-31,5$ \\
3 & Kedalaman & $\mathrm{cm}$ & $32-52$ & $53-63$ & $37-57$ \\
4 & Kecepatan arus & $\mathrm{m} /$ detik & 0 & $0-0,012$ & $0-0,05$ \\
5 & Salinitas & $\% o$ & $27-30$ & $27-30$ & $27-30$ \\
6 & pH & & 6 & 6 & 6 \\
\hline
\end{tabular}

Sumber: Hasil Penelitian, 2016

\section{b. Komposisi Larva Udang Penaeid}

Larva udang penaeid yang tertangkap selama penelitian sebanyak 2.270 individu yang terdiri dari 5 genera yaitu Sicyonia, Trachypenaeus, Xyphopenaeus, Penaeus dan larva tidak teridentifikasi. Komposisi larva udang penaeid yang tertangkap, paling banyak ditemukan adalah larva genus Penaeus dengan jumlah individu tertinggi dan yang paling sedikit adalah larva genus Sicyonia dan larva genus Xyphopenaeus. Adapun Jumlah total individu dari setiap jenis larva udang penaeid yang ditemukan selama penelitian tersaji pada Tabel 2.

Tabel 2.Jenis dan Jumlah Individu Larva Udang Penaeid Selama Penelitian

\begin{tabular}{|c|c|c|c|c|c|c|}
\hline \multirow{2}{*}{ No. } & \multirow{2}{*}{ Genus } & \multicolumn{3}{|c|}{ Wilayah } & \multirow{2}{*}{ Jumlah } & \multirow{2}{*}{$\%$} \\
\hline & & A & $\mathrm{B}$ & $\mathrm{C}$ & & \\
\hline 1 & Sicyonia & 1 & - & 1 & 2 & 0,088 \\
\hline 2 & Trachypenaeus & 61 & 113 & 157 & 331 & 14,581 \\
\hline 3 & Xyphopenaeus & 13 & 1 & - & 14 & 0,617 \\
\hline 4 & Penaeus & 356 & 427 & 1025 & 1808 & 79,648 \\
\hline 5 & Tidak teridentifikasi & 34 & 44 & 37 & 115 & 5,066 \\
\hline & $\Sigma$ individu & 465 & 585 & 1220 & 2270 & 100 \\
\hline
\end{tabular}

Sumber: Hasil Penelitian, 2016

Diagram pie yang menunjukkan jumlah total kelimpahan relatif larva udang penaeid tiap genus yang ditemukan selama penelitian tersaji pada Gambar 2.

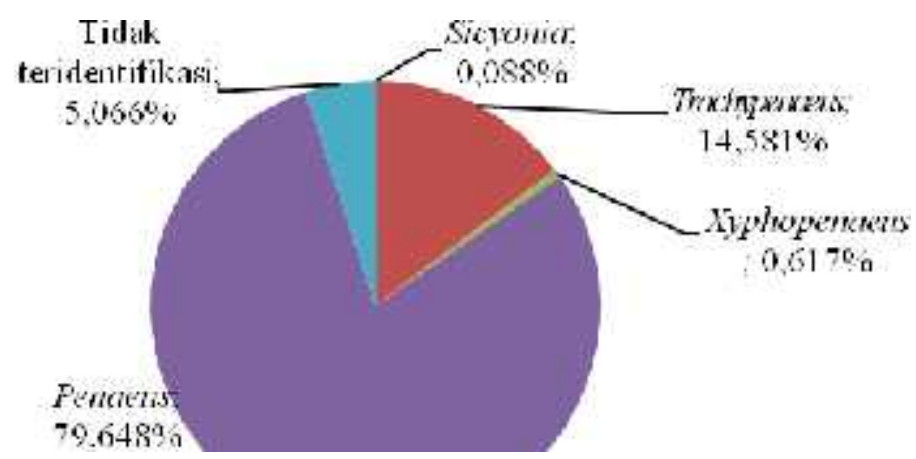

Gambar 2. Komposisi Larva Udang Penaeid Berdasarkan Jumlah Jenis

Berdasarkan Gambar 2 di atas, kehadiran larva genus Penaeus berjumlah 1808 individu dengan presentase $79,648 \%$ dan yang paling sedikit larva genus Sicyonia berjumlah 2 individu dengan presentase 0,088\% dikarenakan genus Sicyonia tidak muncul pada setiap wilayah.

\footnotetext{
${ }^{\circledR}$ Copyright by Management of Aquatic Resources (MAQUARES)
} 
c. Kelimpahan Larva Udang Penaeid

Tabel 3.Kelimpahan Larva Udang Penaeid (ind $/ \mathrm{m}^{3}$ ) Selama Penelitian

\begin{tabular}{ccccc}
\hline No. & Stasiun & Ulangan & $\Sigma \mathbf{n}$ & N (ind $\left./ \mathbf{m}^{\mathbf{3}}\right)$ \\
\hline 1 & & Minggu 1 & 114 & 3 \\
2 & Wilayah A & Minggu 2 & 248 & 7 \\
3 & & Minggu 3 & 103 & 3 \\
4 & & Minggu 1 & 140 & 4 \\
5 & \multirow{2}{*}{ Wilayah B } & Minggu 2 & 279 & 8 \\
6 & & Minggu 3 & 166 & 5 \\
7 & & Minggu 1 & 462 & 13 \\
8 & \multirow{2}{*}{ Wilayah C } & Minggu 2 & 557 & 15 \\
9 & & Minggu 3 & 201 & 6 \\
\hline
\end{tabular}

Sumber: Hasil Penelitian, 2016

Keterangan: $\Sigma \mathrm{n} \quad$ : jumlah individu larva udang penaeid

$\mathrm{N}\left(\mathrm{ind} / \mathrm{m}^{3}\right) \quad$ : kelimpahan larva udang penaeid

Berdasarkan Tabel 3 di atas, kelimpahan larva udang penaeid pada ekosistem mangrove yang tertinggi adalah wilayah Cdiikuti wilayah Bdan yang paling rendah adalah wilayah A. Berikut histogram kelimpahan larva udang penaeid per $\mathrm{m}^{3}$ selama penelitian tersaji pada Gambar 3.

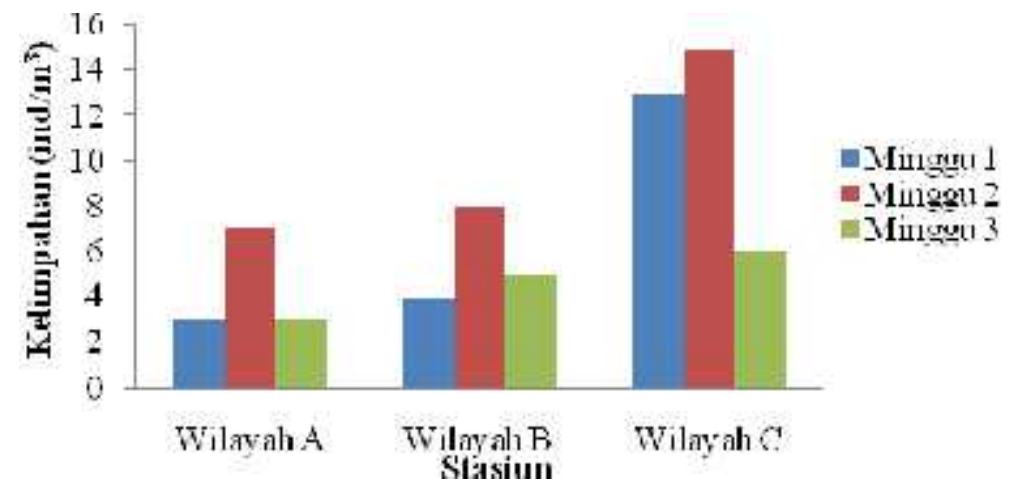

Gambar 3. Histogram Kelimpahan Larva Udang Penaeid Setiap Wilayah

\section{d. Kelas Ukuran Panjang Larva Udang Penaeid}

Pengukuran panjang total larva bertujuan untuk mengetahui kriteria ukuran stadia larva. Kelas ukuran panjang total larva udang penaeid selama penelitian tersaji pada Tabel 5.

Tabel 4.Kelas Ukuran Panjang Total Larva Udang Penaeid Selama Penelitian

\begin{tabular}{cccc}
\hline No. & Kelas Panjang $(\mathbf{m m})$ & Kelas Sedang $(\mathbf{m m})$ & Kelas Pendek $(\mathbf{m m})$ \\
\hline 1 & 8,05 & 5,05 & 3,5 \\
2 & 7,7 & 6,05 & 3,05 \\
3 & 8,4 & 5,3 & 4,05 \\
4 & 8,2 & 5,05 & 4,1 \\
5 & 7,05 & 6,05 & 4,4 \\
6 & 8,5 & 5,7 & 3,4 \\
7 & 7,7 & 6,7 & 3,7 \\
8 & 8,05 & 5,2 & 4,2 \\
9 & 7,25 & 5,5 & 3,4 \\
10 & 7,8 & 6,75 & 4,8 \\
\hline
\end{tabular}

Berdasarkan Tabel 4, diketahui bahwa kelas ukuran panjang total larva udang penaeid selama penelitian dapat dikelompokkan menjadi 3 yaitu: kelompok I berkisar 7 - 8,99 mm, kelompok II berkisar 5-6,99 mm dan kelompok III berkisar 3 - 4,99 mm.

\section{e. Indeks Dominansi (C)}

Nilai indeks dominansi digunakan untuk mengetahui ada atau tidaknya jenis larva udang penaeid yang mendominasi suatu ekosistem. Berikut nilai indeks dominansi tersaji pada Tabel 5. 
Tabel 5.Indeks Dominansi Selama Penelitian

\begin{tabular}{ccc}
\hline No. & Stasiun & C \\
\hline 1 & Wilayah A & 0,371 \\
2 & Wilayah B & 0,331 \\
3 & Wilayah C & 0,523 \\
\hline
\end{tabular}

Sumber: Hasil Penelitian, 2016

Berdasarkan Tabel 5, diketahui bahwa nilai antara $0-0,5$ menunjukkan tidak ada jenis yang mendominasi dan nilai 0,5 - 1 menunjukkan adanya jenis yang mendominasi. Selama penelitian, wilayah A dan B tidak ada jenis yang mendominansi, sedangkan wilayah $\mathrm{C}$ terdapat jenis yang mendominansi. Genus yang mendominansi adalah genus Penaeus, diduga karena kondisi lingkungan yang sesuai bagi kehidupan larva tersebut.

\section{f. Uji Multikolinieritas Antar Variabel}

Uji multikolinieritas antar variabel digunakan untuk menguji apakah antar variabel $\mathrm{X}$ ada tidaknya salingkorelasi.Berikut ini hasil uji kolinieritas pada ekosistem mangrove di Desa Pasar Banggi, Kabupaten Rembang tersaji pada tabel 6.

Tabel 6.Hasil Uji Kolinieritas Antar Variabel

\begin{tabular}{lcccc}
\hline & Suhu & Kecepatan Arus & Kecerahan & Salinitas \\
\hline Suhu & 1,00 & & & \\
Kecepatan Arus & 0,533 & 1,00 & & \\
Kecerahan & 0,082 & 0,310 & 1,00 & 1,00 \\
Salinitas & $-0,385$ & 0,020 & $-0,415$ & \\
\hline
\end{tabular}

Sumber: Hasil Penelitian, 2016

Berdasarkan Tabel 6, diketahui variabel yang memiliki hubungan korelasi yaitu suhu, kecepatan arus, kecerahan dan salinitas dengan tingkat korelasi > 0,6 yang menunjukkan hubungan korelasi kuat.

g. Uji Analisis Regresi Berganda

Tabel 7.Hasil Analisis Regresi Berganda

\begin{tabular}{clcccc}
\hline No. & \multicolumn{1}{c}{ Variabel } & Koefisien & Standar Error & t-statistik & Sig. \\
\hline 1 & Intercep & 86,542 & 25,441 & 3,402 & 0,027 \\
2 & Suhu $\left(\mathrm{X}_{1}\right)$ & $-1,853$ & 0,343 & $-5,410$ & 0,006 \\
3 & Kecepatan arus $\left(\mathrm{X}_{2}\right)$ & 291,783 & 53,203 & 5,484 & 0,005 \\
4 & Kecerahan $\left(\mathrm{X}_{3}\right)$ & $-0,280$ & 0,116 & $-2,409$ & 0,074 \\
5 & Salinitas $\left(\mathrm{X}_{4}\right)$ & $-0,599$ & 0,557 & $-1,076$ & 0,343 \\
6 & $\mathrm{R}^{2}$ & & & 0,918 & \\
7 & Adj. $\mathrm{R}^{2}$ & & & 0,837 & \\
8 & F-statistik & & 11,259 & \\
\hline
\end{tabular}

Sumber: Hasil Penelitian, 2016

Berdasarkan Tabel 7, diperoleh konstanta $b_{0}=86,542$, koefisien regresi $b_{1}=-1,853, b_{2}=291,783, b_{3}=-$ 0,280 dan $b_{4}=-0,599$. Persamaan regresi linier ganda adalah:

$$
\mathrm{Y}=86,542-1,853 \mathrm{X}_{1}+291,783 \mathrm{X}_{2}-0,280 \mathrm{X}_{3}-0,599 \mathrm{X}_{4}
$$

Hasil analisis menunjukkan harga statistik untuk koefisien variabel $X_{1}$ yaitu $t_{\text {hit }}=-5,410$ dan $p$-value $=$ $0,006 / 2=0,003<0,05$ atau $\mathrm{H}_{0}$ ditolak yang berarti suhu berpengaruh positif terhadap kelimpahan larva udang penaeid, variabel $\mathrm{X}_{2}$ yaitu $\mathrm{t}_{\text {hit }}=5,484$ dan $\mathrm{p}$-value $=0,005 / 2=0,002<0,05$ atau $\mathrm{H}_{0}$ ditolak yang berarti kecepatan arus berpengaruh positif terhadap kelimpahan larva udang penaeid, variabel $\mathrm{X}_{3}$ yaitu $\mathrm{t}_{\text {hit }}=-2,409$ dan p-value $=0,074 / 2=0,037<0,05$ atau $\mathrm{H}_{0}$ ditolak yang berarti kecerahan berpengaruh positif terhadap kelimpahan larva udang penaeid dan variabel $\mathrm{X}_{4}$ yaitu $\mathrm{t}_{\text {hit }}=-1,076$ dan p-value $=0,343 / 2=0,172>0,05$ atau $\mathrm{H}_{0}$ diterima yang berarti salinitas berpengaruh negatif terhadap kelimpahan larva udang penaeid.

\section{Pembahasan}

\section{a. Jenis Larva Udang Penaeid}

Larva udang penaeid yang diperoleh selama penelitian terdiri dari 5 genera dari 2 stadia yang tertangkap dengan scoop netpada ekosistem mangrove yaitu stadia mysis dan post-larva. Menurut Panjaitan et al. (2014), stadia zoea dan mysis adalah fase pertumbuhan cepat dan merupakan fase yang sangat kritis karena pada saat itu larva udang sangat rentan dan sering terjadi tingkat kematian yang tinggi. Nauplius dengan cadangan nutrien 
yang tinggi memiliki kemungkinan untuk bertahan hidup selama bermetamorfosis menjadi zoea dan selama stadia zoea dan mysis terjadi adaptasi fisiologis dengan makanan yang berasal dari luar.

Jenis larva udang penaeid yang ditemukan secara keseluruhan yaitu genus Sicyonia, Trachypenaeus, Xyphopenaeus dan Penaeus dengan jumlah total sebanyak 2.155 individu dan larva yang tidak teridentifikasi (unidentified) sebanyak 115 individu. Jenis larva udang yang paling banyak ditemukan dari famili Penaeidae adalah Penaeus dengan jumlah 1.808 individu (79,648\%) diikuti oleh Trachypenaeus dengan jumlah 331 individu (14,581\%), Xyphopenaeus dengan jumlah 14 individu (0,617\%), Sicyonia dengan jumlah 2 individu $(0,088 \%)$ dan larva tidak teridentifikasi dengan jumlah 115 individu (5,066\%). Jenis yang ditemukan paling sedikit adalah Sicyonia.

\section{b. KelimpahanLarva Udang Penaeid}

Kelimpahan larva udang penaeid per $\mathrm{m}^{3}$ pada ketiga wilayah berbeda-beda. Pada minggu pertama, kelimpahan larva udang di wilayah A $3 \mathrm{ind} / \mathrm{m}^{3}$, wilayah B $4 \mathrm{ind} / \mathrm{m}^{3}$ dan wilayah C $13 \mathrm{ind} / \mathrm{m}^{3}$. Pada minggu kedua, kelimpahan larva udang di wilayah A $7 \mathrm{ind} / \mathrm{m}^{3}$, wilayah B $8 \mathrm{ind} / \mathrm{m}^{3}$ dan wilayah C $15 \mathrm{ind} / \mathrm{m}^{3}$. Pada minggu ketiga, kelimpahan larva udang di wilayah A $3 \mathrm{ind} / \mathrm{m}^{3}$, wilayah B $5 \mathrm{ind} / \mathrm{m}^{3}$ dan wilayah C 6 ind $/ \mathrm{m}^{3}$. Kelimpahan larva paling banyak ditemukan pada ketiga wilayah selama penelitian adalah wilayah $\mathrm{C}$, diikuti wilayah B dan yang paling sedikit adalah wilayah A.

Perbedaan nilai kelimpahan diduga dipengaruhi oleh larva yang masuk dari perairan laut yang tertangkap, teknis pengambilan sampel dengan kendala peneliti bergerak lambat di wilayah A dan B dikarenakan perakaran mangrove serta stadia pada masing-masing wilayah misalnya, stadia juvenil dominan di mangrove umur 50 tahun (wilayah A) dengan kriteria sudah seperti udang dewasa, sedangkan stadia post-larva dominan di mangrove umur 3 tahun (wilayah C) dengan kriteria duri rostrum sudah berukuran panjang, kaki jalan dan kaki renang sudah terlihat perbedaannya. Sama halnya dengan penelitian Kembaren dan Suprapto (2011), kelimpahan larva udang Penaeidae cenderung dominan ditemukan pada stasiun 10 , yaitu berkisar antara $12-16 \mathrm{ind} / \mathrm{m}^{3}$. Stasiun 10 berada di bagian utara muara Sungai Sambas atau perairan Jawa. Area ini bukan merupakan lokasi penangkapan udang bagi para nelayan, sehingga area ini sangat sesuai untuk daerah asuhan bagi udang Penaeidae.

Menurut Nybakken (1992) dalam Sembiring (2008), seperti diketahui perairan dengan tumbuhan yang cukup merupakan tempat paling ideal bagi kehidupan udang. Kecilnya kelimpahan larva udang juga dipengaruhi oleh kompetisi ruang, predator seperti ketika sampling ditemukan ular dan ubur-ubur. Menurut Arshad et al. (2010), besar kecilnya arus pasang surut serta kondisi lingkungan merupakan faktor utama yang dapat menyebabkan perubahan pada kelimpahan, distribusi serta spesies yang ada dalam suatu habitat. Selain itu, larva juga mencari kondisi lingkungan yang sesuai dan kebutuhan makanan untuk pertumbuhannya ke daerah mangrove. Menurut Wakwabi dan Jaccarini (1993), menunjukkan bahwa siklus pola makan lebih berpengaruhpada kelimpahan larva di air permukaan daripada siklus pasang surut pada larva penaeid.

\section{c. Indeks Dominansi}

Indeks dominansi larva udang penaeid pada wilayah A 0,371, wilayah B 0,331 dan wilayah C 0,523. Nilai ini menujukkan pada wilayah A dan B tidak terdapat dominansi suatu genus, sedangkan wilayah $\mathrm{C}$ terdapat dominansi genus tertentu. Berdasarkan hasil data yang diperoleh, genus Penaeus mempunyai jumlah terbanyak sebesar 1.808 individu. Nilai menunjukkan bahwa selama penelitian larva genus Penaeus mendominansi di ekosistem mangrove. Besarnya nilai dominansi menunjukkan adanya kaitan terhadap faktor fisika, kimia dan biologi serta faktor lingkungan biotik dan abiotik. Menurut Wedjatmiko dan Cholik (1989) dalam Sembiring (2008), akar-akar pohon bakau selain baik bagi larva udang juga sebagai tempat berlindung dari serangan predator sampai tumbuh menjadi udang muda, bakau juga menyediakan bahan organik kaya nutrisi yang diperlukan untuk pertumbuhan udang.

\section{d. Hubungan dan Pengaruh Variabel Kualitas Air Terhadap Kelimpahan Larva Udang Penaeid}

Uji multikolinieritas digunakan untuk mengetahui hubungan antar variabel kualitas air (independen). Hasil uji multikolinieritas antar variabel yaitu suhu, kecepatan arus, kecerahan dan salinitas menunjukkan hubungan korelasi yang kuat dengan tingkat korelasi $>0,6$. Kecepatan arus berpengaruh terhadap pergerakan larva di sekitar ekosistem mangrove. Suhu berpengaruh terhadap pertumbuhan larva udang. Menurut Haliman (2005) dalam Kanwilyanti (2013), suhu optimal pertumbuhan larva udang antara $26-32^{\circ} \mathrm{C}$. Menurut Pratiwi (2009), salinitas merupakan faktor lingkungan yang sangat mempengaruhi keberadaan mangrove dan kehidupan krustasea.

Berdasarkan persamaan regresi Kelimpahan =86,542-1,853Suhu +291,783KecepatanArus 0,280Kecerahan -0,599Salinitas, dapat dijelaskan pengaruh variabel independen yaitusuhu, kecepatan arus, kecerahan dan salinitas adalah sebagai berikut:

Suhu mempunyai pengaruh negatif terhadap kelimpahan larva udang penaeid, artinya jika suhu meningkat akan menyebabkan penurunan kelimpahan larva udang penaeid. Menurut Haliman (2005) dalam Kanwilyanti (2013), suhu berpengaruh langsung pada metabolisme udang, pada suhu tinggi metabolisme udang

$$
{ }^{\circ} \text { Copyright by Management of Aquatic Resources (MAQUARES) }
$$


dipacu, sedangkan pada suhu yang lebih rendah proses metabolisme diperlambat. Bila keadaan seperti ini berlangsung lama, maka akan mengganggu kesehatan udang karena secara tidak langsung suhu air yang tinggi menyebabkan oksigen dalam air menguap, akibatnya larva udang akan kekurangan oksigen.

Kecepatan arus mempunyai pengaruh positif terhadap peningkatan kelimpahan larva udang penaeid, artinya jika kecepatan arus meningkat akan menyebabkan peningkatan kelimpahan larva udang penaeid. Menurut Romimohtarto dan Juwana (2004) dalam Riyana (2015), arus yang membuat mereka melakukan pergerakan dari satu tempat ke tempat lain atau arus juga bermanfaat menyebarkan larva ke berbagai arah. Bagi hewan yang bersifat planktonik ini termasuk larva udang, arus pasang surut bermanfaat untuk membawa mereka bergerak hingga muara sungai.

Kecerahan mempunyai pengaruh negatif terhadap penurunan kelimpahan larva udang penaeid, artinya jika kecerahan meningkat akan menyebabkan penurunan kelimpahan larva udang penaeid. Menurut Kanwilyanti (2013), kecerahan berpengaruh terhadap kelimpahan pakan alami untuk larva udang, dimana kecerahan menentukan radiasi sinar matahari yang masuk ke perairan untuk proses fotosintesis fitoplankton yang nantinya menjadi pakan alami larva udang sebagai zooplankton.

Salinitas mempunyai pengaruh negatif terhadap penurunan kelimpahan larva udang penaeid, artinya jika salinitas meningkat akan menyebabkan penurunan kelimpahan larva udang penaeid. Menurut Darmono (1991) dalam Sembiring (2008), tingkat salinitas dapat mempengaruhi penyebaran spesies dari udang. Kadar garam optimum untuk udang dapat hidup normal dan tumbuh baik adalah pada 15\%o-30\%o. Perubahan kadar garam yang mendadak dapat menyebabkan angka kematian yang tinggi.

Berdasarkan hasil analisis regresi berganda antara kelimpahan larva udang penaeid dengan faktor kualitas air, nilai koefisien korelasi (R) 0,958 artinya suhu, kecepatan arus, kecerahan dan salinitas berpengaruh terhadap kelimpahan larva udang penaeid sebesar $95,8 \%$ yang berarti berhubungan kuat dan nilai koefisien determinasi $\left(\mathrm{R}^{2}\right)$ 0,918 artinya kelimpahan larva udang penaeid 91,8\% dipengaruhi oleh suhu, kecepatan arus, kecerahan, salinitas dan $8,2 \%$ dipengaruhi oleh variabel lain.

Secara keseluruhan kelimpahan larva udang penaeid sangat dipengaruhi oleh kualitas air. Hal ini disebabkan karena adanya siklus pola makan dan penyebaran larva udang penaeid yang dipengaruhi oleh arus. Oleh karena itu, kelimpahan larva udang penaeid akan berbeda di setiap wilayah penelitian sesuai dengan kondisi perairan itu sendiri.

\section{KESIMPULAN}

Kesimpulan yang dapat diambil dari penelitian adalah sebagai berikut:

1. Jenis larva udang penaeid yang teridentifikasi adalah Sicyonia, Trachypenaeus, Xyphopenaeus, Penaeus dan terdapat sejumlah kecil sampel larva yang tidak teridentifikasi;

2. Kelimpahan larva udang penaeid yang tertinggi selama penelitian di wilayah $\mathrm{C}$, diikuti wilayah $\mathrm{B}$ dan paling sedikit wilayah A. Kelimpahan relatif larva udang penaeid adalah genus Sicyonia 0,088\%, genus Trachypenaeus 14,581\%, genus Xyphopenaeus 0,617\%, genus Penaeus 79,648\% dan larva tidak teridentifikasi 5,066\%. Indeks dominansi wilayah A dan B tidak ada jenis yang mendominansi, sedangkan wilayah $\mathrm{C}$ terdapat jenis yang mendominansi; dan

3. Hasil uji multikolinieritas yaitu suhu, kecepatan arus, kecerahan dan salinitas menunjukkan hubungan korelasi kuat. Variabel suhu, kecepatan arus dan kecerahan mempengaruhi kelimpahan udang penaeid secara nyata, salinitas tidak mempengaruhi kelimpahan udang penaeid secara nyata.

\section{UCAPAN TERIMA KASIH}

Terima kasih penulis ucapkan kepada Dr. Ir. Pujiono W. Purnomo, MS, Ir. Anhar Solichin, M.Si dan Dra. Niniek Widyorini, MS , Churun Ain, S.Pi, M.Si, yang telah memberikan arahan, bimbingan, serta kritik dan saran dalam penyusunan jurnal ini. Serta semua pihak yang telah membantu dan memberikan dukungan.

\section{DAFTAR PUSTAKA}

Arshad, A., S.M.N. Amin and N. Osman. 2010. Population Parameters of Planktonic shrimp, Lucifer intermedius (Decapoda: Sergestidae) from Sungai Pulai Seagrass Area Johor, Peninsular Malaysia. Sains Malaysiana, 39(6):877-882.

Dall, W., B.J. Hill, P.C. Rothlisberg and D.J. Sharples. 1990. Marine Biology. Academic Press, London, 489 p.

Kadir. 2015. Statistika Terapan Konsep, Contoh dan Analisis Data dengan Program SPSS/ Lisrel dalam Penelitian. PT. Raja Grafindo Persada. Depok. 517 hlm.

Kanwilyanti, S. 2013. Kelimpahan Larva Udang di Sekitar Perairan PT. Kayu Lapis Indonesia, Kaliwungu, Kendal. [Skripsi]. Fakultas Perikanan dan Ilmu Kelautan, Universitas Diponegoro, Semarang, 71-80 hlm. 
Kembaren, D.D. dan Suprapto.2011. Komposisi dan Distribusi Larva Udang di Perairan Pemangkat dan Sekitarnya. Dalam: Prosiding Forum Nasional Pemacuan Sumber Daya Ikan III Tanggal 18 Oktober 2011, pp. 1-9.

Naamin, N. 1975. Beberapa Cara Pengenalan dan Kunci Identifikasi Larva, Post-Larva dan Juvenile Udang Penaeid. Lembaga Penelitian Perikanan Laut, Jakarta, 45 hlm.

Odum. E.P. 1993. Dasar-Dasar Ekologi. Ed. III. Gadjah Mada University Press, Yogyakarta, 696 hlm.

Panjaitan, A.S., W. Hadie dan S. Harijati. 2014. Pemeliharaan Larva Udang Vaname (Litopenaeus Vannamei, Boone 1931) dengan Pemberian Jenis Fitoplankton yang Berbeda. Jurnal Manajemen Perikanan dan Kelautan., 1(1): 1-12.

Pratiwi, R. 2009. Komposisi Keberadaan Krustasea di Mangrove Delta Mahakam Kalimantan Timur. MAKARA, SAINS., 13(1): 65-76.

Riyana, H. 2015. Kelimpahan Larva Udang Penaeid pada Saat Pasang di Saluran Tambak Desa Gempolsewu, Kabupaten Kendal. [Skripsi]. Fakultas Perikanan dan Ilmu Kelautan, Universitas Diponegoro, Semarang, 49-57 hlm.

Sembiring, H. 2008. Keanekaragaman dan Distribusi Udang Serta Kaitannya dengan Faktor Fisik Kimia di Perairan Pantai Labu Kabupaten Deli Serdang. [Tesis]. Sekolah Pascasarjana, Universitas Sumatera Utara, Medan, $101 \mathrm{hlm}$.

Wakwabi, E.O. and V. Jaccarini. 1993. The distribution and Abundance of Planktonic Penaeid Larvae in Tudor Creek, Mombasa, Kenya. Hydrobiologia., 264: 185-192. 